\title{
PROTECTION OF THE CIVILIAN POPULATION AS THE IMPLEMENTATION OF THE PRINCIPLE OF DISCRIMINATION
}

\author{
Al Qodar Purwo Sulistyo ${ }^{1^{*}}$ Levina Yustitianingtyas ${ }^{2}$ \\ ${ }^{1 * 2}$ Faculty of Law, University of Muhammadiyah Surabaya, Indonesia, alqodar@ fh. um-surabaya.ac.id \\ (corresponding).
}

\begin{abstract}
Legal research aims to solve the problems that arise in connection with the application of the principle of distinction (distinction principle) in terms of the protection of civilians in international armed conflict between Israel and the Palestinians. The object of study in legal research is devoted to applying the principle of distinction against the civilian population as a victim of war under international humanitarian law in armed conflict international. To solve these problems, they need to be supported by the data in the form of legal material. The data was obtained through the study of literature and via the Internet. From this legal research to achieve results that provide answers to the problems that exist, the Israeli aggression on Palestine has violated international humanitarian law provisions and has caused misery for the Palestinian population. As a result of these actions, the Israelis may be subject to liability in the form of sanctions or punishment according to international humanitarian law provisions applicable in the international community.
\end{abstract}

Keywords: civilians, distinction principle, humanitarian law

\section{INTRODUCTION}

In many parts of the world today, there are many disputes or disputes between countries, both between member states United Nations (U.N.) and between U.N. member states and non-member states of the United Nations. Regardless of the form of the dispute and who is involved in the dispute can impact the disruption of international peace and security. Another impact arising from these armed conflicts is the onset of humanitarian issues. Thus, it invites the U.N. humanitarian agencies to help the conflict (in this case, the civilian population). Their rights were violated due to armed clashes in a territory of the State.

One example of the international conflict raised as an issue in this article and still ongoing in the Middle East conflict is a conflict or armed conflict between
Israel and the Palestinians, otherwise known as the Gaza Strip conflict. The level of dispute between the two countries has been deemed to be a disturbance of international peace and security. As a result, the conflict has certainly caused a lot of harm that many human rights violations occurred. Of course, the civilian population is affected because their life rights have been violated due to the conflict. Many of them are deprived of housing, families, jobs and many more of their living rights constrained by the battle (Arianta et al., 2020).

Israeli aggression to Palestine is a Middle East conflict that has been going on since 1920. This conflict every year is not getting retroactive but instead growing. In mid-2014, in June, the beginning of a reoutbreak of Israel and Hamas's conflict, Israel resumed attacks on Palestinians. The attack came in the background of three Jewish teenagers studying in 
Gaza's West Bank kidnapped by Palestinians known to be close to Hamas and then three Jewish teenagers found dead on June 10, 2014. Israel has accused Hamas of kidnapping and murder. Shortly after that, Israel retaliated, which caused a state of emergency and heat. A young Palestinian man was kidnapped and alleged to have been burned alive by people thought to be from a hardline Jewish group (Fadila, 2014). Open strife broke out. Hamas and other militant groups inhabiting Gaza launched dozens of rockets into Israeli territory, immediately responding with much larger airstrikes.

On July 6, Israeli airstrikes in Gaza killed seven Hamas fighters, while Hamas stepped up its rocket attacks on Israel. On July 8, 2014, the Israeli Defense Forces (IDF) launched Operation Protective Edge in the Gaza Strip. On July 13, the Israeli military reported that more than 1,300 Israeli airstrikes had been launched into Gaza, while more than 800 rockets had been fired from Gaza into Israel. The next day, July 14, Egypt announced a ceasefire initiative. The Israeli Government accepted this proposal and temporarily halted the attack on the morning of July 15 . However, all Palestinian factions, including Palestinian President Abbas, announced that they had not been informed of the Egyptian initiative and only learned through the media. Hamas and other Palestinian factions reject "the current version (of the agreement). On July 16, Hamas and Islamic Jihad offered Israel a 10-year ceasefire on ten terms, mostly alluding to the Gaza Strip blockade (Wikipedia, 2014).

In any armed conflict, it inevitably inflicts many casualties from various parties. Therefore, international humanitarian law establishes the distinction principle, which is a principle that distinguishes the population from a country that is at war, or that is engaged in armed conflict, into two) dan civilian population (factions, namely Combatant sand civilians. Combatants are a group of people who actively participate in hostilities, while civilians are the population who do not participate in hostilities (Haryomataram, 2000). The need for such distinction is to know who can participate in hostilities or who is protected or does not participate in hostilities to be targeted for attack.

The issue of the protection of the civilian population during war or armed conflict instead of war ultimately spawned an international convention, namely the Geneva IV Convention of 1949 on the protection of civilians in armed conflict (Revelation, 2018), which contains about:
1. Protection of enemy civilians in enemy territory and occupied territories;

2. Protection of civilians in the area of the warring parties;

3. Protection of civilians in the occupied territories;

4. Protection of interned/interned civilians.

Before the birth of the Geneva IV Convention of 1949, the three previous Geneva Conventions of 1949 only contained or regulated the protection of war victims from the warring parties in the condition of wounds, sick, protection for prisoners of war. The Geneva IV Convention of 1949 was the first convention specifically governing civil war casualties during the armed conflict. The articles in the convention describe the rights and obligations of the warring parties to civilians in conflict or armed strife situations.

The protection of civilians was then re-described or expanded in the Additional Protocol of the Geneva Conventions, better known as the Additional Protocol of 1977. The 1977 Additional Protocol stipulated that to ensure the honor and protection of civilians and civilian objects, the parties involved in the conflict must distinguish between civilians and combatants and between civilian objects and military objects so that military operations are directed only at military targets. But in reality, Israeli military action against the Palestinians cannot distinguish between civilian objects and military objects. At the same time, the Hamas side also carries out the same attacks as Israeli forces do.

Protection for civilians is as strong as the protection afforded to combatants and those in hors de combat (no longer able to fight). This is stated in the United States Army Lieber Code 1863 (Lieber's Instruction in 1863), Article 44, which states that:

All wanton violence committed against persons in the invaded country, all destruction of property not commanded by the authorized officer, all robbery, all pillage or sacking, even after taking place by main force, all rape, wounding, maiming, or killing of such inhabitants, is prohibited under the penalty of death, or such another severe punishment as may seem adequate for the gravity of the offense.

Lieber's instruction stipulates that prohibitions be imposed on all cruel acts committed against persons in the area of assault, all destruction of property not ruled by an unlicensed Officer, all robberies and thefts, even after the seizure of territory by a violent act, all acts of 
Al Qodar Purwo Sulistyo,

Levina Yustiningtyas

pp. $94-104$
E-ISSN : 2723-2476

Issn : 2723-1968

ACLJ, Vol. 1, Issue 2, 2020 rape or murder against the population are prohibited with the threat of the death penalty.

Paying attention to such conditions is appropriate if Israel is to take responsibility for all the tribulations in Palestine. Due to his blinding attacks, many civilians were victimized. The material loss of the Palestinian city's order consisting of various public facilities and the Palestinian Government's chaos resulted from Israel's military action to disown Hamas. Based on the fact that Israel's military action to Palestine cannot sort between civilian objects and military objects. Many carry out mistargeted attacks that hit civilian settlements resulting in them (toddlers, children, adults, the elderly) being killed because Israel wants to destroy its enemy Hamas. In writing, this law examines the extent of the application of distinction principles attached to the protection of civilians as victims of war according to international humanitarian law in armed conflict.

\section{RESEARCH METHODS}

This legal research is normative juridical with a statute approach. Normative juridical legal research is a study that deductively begins an analysis of the articles in the legislation governing the above issues. Juridical legal research means research that refers to existing literature studies or secondary data used. In contrast, normative means legal research aims to obtain normative knowledge about the relationship between one rule and another regulation and application in practice.

A statute approach is an approach to reviewing all laws and regulations that are caught up with the legal issues raised.

\section{RESULTS AND DISCUSSIONS}

\section{Distinction Principle}

The distinction Principle is an important principle in humanitarian law, which is a principle that distinguishes or divides the population from a country that is at war or is engaged in armed conflict into two groups, namely Combatant and Civilian Population. A combatant is a group of people who actively participate in hostilities, while the civilian population is a group of people who do not participate in hostilities. The need for such distinction is to know those who may participate in hostilities to be targeted or objected to violence and those who cannot participate in hostilities so that they are not made objects of violence. This is very important to emphasize because the war only applies members of the armed forces from hostile countries. Meanwhile, civilians who do not participate in the hostilities must be protected from such actions.

According to Jean Pictet in Arlina Permanasari's book, this distinguishing principle stems from a general principle called the principle of restriction, which states 'the civilian population and individual civilians should enjoy general protection against danger arising from military operations'. In this principle, further implementation or implementation is required into several implementation principles as a result of this referred to as principles of application, namely:

1. The parties in the dispute must distinguish between combatants and civilians to save civilians and civilian objects.

2. Civilians, as well as civilians individually, should not be used as objects of attack even in the case of reprisals.

3. Acts and threats of violence are prohibited, whose primary purpose for spreading terror against civilians.

4. The parties to the dispute should take all precautionary measures and allow for civilians' rescue or at least to suppress accidental loss or damage to be as small as possible.

5. Only members of the armed forces have the right to attack and detain the enemy.

In International Humanitarian Law, it is also regulated regarding the provision of protection of civilians based on specific classifications of size in the event of armed colic stipulated in the Geneva Convention 1949 on the protection of civilians in armed conflicts, namely (Yustitianingtyas, 2007) :

1. Arrangements on areas within the disputed territory, among others:

a. Hospitals and regions and safe locations are free from attacks in the event of hostilities. (article 14 of the Geneva Conventions 1949).

b. Neutralized areas. (article 15 of the Geneva Conventions 1949).

c. Special regions are based on specific agreements to evacuate war (article 17 of the Geneva Conventions 1949).

2. Arrangements on protection against installation and medical personnel, among others:

a. prohibition of attacks on public hospitals (article 18 of the Geneva Conventions 1949). 
b. Protection afforded to hospital staff or health service members (article 20 of the Geneva Conventions 1949).

c. protection directed against aircraft or health transport (article 21 and article 22 of the Geneva Convention 1949), which includes the delivery of humanitarian aid/medicine (article 23 of the Geneva Conventions 1949)

3. Protection for people who are under certain conditions, namely:

a. people who are injured or sick and weak people and women who are pregnant at the time of hostilities (article 23 of the Geneva Conventions 1949).

b. children separated from their families and orphans (article 24 of the Geneva Conventions 1949) and family members who lost families or siblings (article 26 of the Geneva Conventions 1949).

As stipulated in the 1949 Geneva Conventions, general protection stipulated to civilians should not be discriminatory. As mentioned in article 27, following article 34 of Convention IV, those (civilians) must not take the following actions:

1. Perform physical and spiritual coercion to gain information;

2. Perform actions that cause physical suffering;

3. Imposing collective punishment;

4. Commit intimidation, terrorism, and robbery;

5. Retaliation (reprisal);

6. Make merka as a hostage;

7. Perform actions that cause physical suffering or hostility to the protected persons.

Based on the description of the principles applicable in the above international humanitarian law, that in fact, there are many violations due to the conflict between Israel and Palestine, because many provisions of humanitarian law and provisions that have been established by the convention are violated by both parties, namely the protection of the civilian population in which case the principle of discrimination is ignored.

The attacks targeted by hostilities are also out of place. As a result of this armed conflict, thousands of Palestinians have been killed, and the Palestinian city's facilities and infrastructure destroyed, leaving virtually no shelter for Palestinians.

\section{Protection of Civilians in International Humanitarian Law}

Protection of civilians as a result of or due to armed strife essentially obtains arrangements in humanitarian law. However, in its development in protecting the protection of the civilian population due to armed clashes in his country can be carried out through other means, such as the transfer of residents to areas that are not used as an arena of contention, but still within the territory of the warring countries, the transfer of residents to other safe areas of the country (refugees), or carrying out the displacement of residents (Emigrants) as is the case in Iraq around 2003. At the time, about 1.5 million Iraqis were sought safe haven outside the city of Baghdad due to the fighting. Likewise, about 7,000 Iraqis are asylum seekers in Damascus and Amman. In comparison, some Iraqis left their cities or countries for Syria and Jordan as emigrants (Zouhair Al Hassani, 2008).

In one of the Jurisprudence of The Law produced by the ICTY (International Criminal Tribunal for the former Yugoslavia) explaining about when a conflict can be classified in an armed conflict determined as described by Marco Sassoli, Antonie B. Bouvier, that the armed conflict in question is an armed conflict that occurs when there is an attempt to use the force of the armed forces by one State to another, or there has been measurable armed violence between the legitimate Government of a State against an organized armed group, or an organized armed group, or between armed groups organized with other armed groups within a territory of the State (Sassoli, Marco, 1999).

\section{Provisions of International Law in International Armed Conflict}

The principles in international humanitarian law are applied in all armed conflicts, and in those principles govern the conduct of the parties to the conflict. The purpose of humanitarian law is in principle to protect those who suffer from war or as victims of war, whether they are actively participating in hostilities or those who are not active in hostilities (Rizal, 2016).

Humanitarian law has a close relationship with human rights. The principles of human rights and humanitarian law have the same purpose as the protection of people. Although humanitarian law is codified first, it is felt that humanitarian law becomes part of human rights law that applies in times of armed conflict.

The international conflict between Israel Palestine that occurred from a few years ago to the present, when considered from aspects of international 
Al Qodar Purwo Sulistyo,

Levina Yustiningtyas

pp. $94-104$
E-ISSN : 2723-2476

Issn : 2723-1968

ACLJ, Vol. 1, Issue 2, 2020 law there is a crime of aggression, which fall into the category of crimes that fall under the jurisdiction of the International Criminal Court, and gross violations of human rights. The scope of gross violation of human rights is comprehensive, including violations of humanitarian law (Muladi, 2000).

\section{Humanitarian law applies in International Armed Conflicts}

As it is known, the International Humanitarian Law is part of the Law of War, and the law of war itself is part of International Law. The law of war is the oldest part of international law, and most of the laws of war are written or codified laws.

In simple terms, International Humanitarian Law can be given an understanding as a law governing the protection of war victims. From this simple understanding, two activities can be observed, namely war activities and war victims' protection activities. International Humanitarian Law protects victims of war or those involved in combat can be broadly categorized into; First, the protection afforded to combatants, namely those who are actively involved in combat. The form of protection given to him is the status of a prisoner of war if it turns out to be in the opposing side's hands. As prisoners of war, they must be treated humanely and guaranteed their rights and obligations. Second, the protection afforded to civilian populations, namely, residents of the warring parties who are not actively involved in the fighting.

It is necessary to be affirmed here about the term Civilian population, i.e., all people who are classified as civilians; Civilians are persons who are not included in those protected by Article $4 \mathrm{~A}(1,2,3$, and 6) of Convention III, which states that: a). members of the armed forces of the warring parties and members of the militia or corps who are part of the armed forces, b). members of other militias, voluntary corps, including organized resistance movements that belong to a warring party and operate outside or on their own territory, as long as they meet certain conditions, c). Members of the regular armed forces who declare allegiance to a government not recognized by the retaining State, d). Levee en masse, if it falls into enemy hands, will gain status as prisoners of war, whereas civilian objects are all objects that are not military targets. The form of protection given to him is a prohibition against making them an object or target of attack. Third, protection is given to the person who should be respected and should not be targeted by an attack because of his work.
The form of protection is positively related to one of the principles or principles in humanitarian law, namely the Distinction Principle. This principle confirms that the inhabitants of a country involved in an armed dispute or war are distinguished from combatants. The background of the emergence of this principle is to know who can participate in armed clashes or wars and who is not and determine who can be targeted by the attack and who is not. Each of these groups, in addition to having different rights and obligations, as well as different consequences concerning the enemy. However, on the other hand, they have the same rights, which is to be treated humanely. Therefore, in the circumstances of armed strife or war, one must determine the choice he will enter into which group, one at the same time, cannot enter into two groups.

The distinction principle in an armed conflict is necessary because in war, combatants are the parties to the war, and they are the targets in the war. The civilian population in every battle must be protected and not used as a target for war. The aspects of the distinguishing principle are used or applied to establish the rights and obligations of the parties in an armed conflict. The purpose of the humanitarian law can be achieved to humanize armed conflict further. The protection aspect has a critical function in the civilian population. The civilian population in any armed conflict is always in a weak position and always accepts directly the consequences of bad or misery inflicted in armed conflict. According to Hans Peter Gasser, the weak position is formed from two activities in each hostility, namely the danger of direct military operations during armed clashes and the dangers that arise when the civilian population is in enemy control (Hans-Peter, n.d.)

Humanitarian law applies in an armed conflict in the event of an armed conflict, but its enforcement must go through certain mechanisms. This mechanism is governed by the Geneva Conventions, which is the mechanism by using the national legal tool, and its arrangements are contained in The Additional Protocol I of 1977, namely with the commission of the International Fact-Finding Commission. In addition to two agents regarding International Humanitarian Law Enforcement can also be done through international judicial institutions, both ad hoc and permanent courts.

Under the Geneva Conventions, general protection stipulated to civilians should not be discriminatory. In all circumstances, the civilian population is entitled to general protection consisting 
of personal respect, family rights of wealth, and practice of its religious teachings. It must be treated under humanitarian principles, protected from any threat of violence, acts of power, and humiliation. Against them should not be taken actions as mentioned in Article 27 by Article 34 of Convention IV, namely as follows:

1. Perform physical and spiritual coercion to gain information;

2. Perform actions that cause physical suffering;

3. Imposing collective punishment;

4. Commit intimidation, terrorism, and robbery;

5. Retaliation (reprisal);

6. Taking them hostage;

7. Perform actions that inflict physical suffering or hostility toward protected persons.

\section{Gross Violations in the Perspective of International Humanitarian Law and Human Rights}

Cases of gross violation of human rights are fascinating because such crimes have a unique nuance that experts call a special form of political crimes. Political crimes can be distinguished over, first, crimes against Government such as illegal demonstrations, terrorists, separatist movements, and so on; second, human rights violations committed by the authorities

(crimes by government or state crimes or governmental crimes), such as violations of the law by the authorities, kidnapping, and torture by the security forces, mass killings by or facilitated by the Government (Muladi, 2000). According to Frank E Hagan, those gross human rights violations have a special nuance: the abuse of power in the sense of perpetrators doing in Government and facilitated by government power (Muladi, 2000).

Gross violation of human rights is a criminal offense, as is another unlawful crime, and there is no justification. But there are special things that distinguish from other crimes (ordinary crimes) or at least so. In severe human rights violations, there are several elements:

1. The abuse of power, in terms of association with the Government. This includes the socalled violation by omission.

2. The crime is considered degrading to human dignity and violates fundamental humanitarian principles.
3. The act was condemned internationally.

4. Performed systemically and widely (Muladi, 1998).

Before the understanding of crimes against humanity is agreed as contained in Article 7 of the Rome Statute, the International Law Commission ( ILC) means crimes against humanity are to include serious inhuman acts involving widespread or systematic violations directed at the civilian population, rising in whole or in part (Hasiholan Gultom, n.d.). Meanwhile, according to M. Cherif Bassiouni in his book Erikson Hasiholan Gultom, the Competence of the International Criminal Court in the Criminal Justice against Humanity in East Timor, the crime against humanity is a crime committed on a massive scale against a group of identifiable people (Hasiholan Gultom, n.d.).

Furthermore, M. Cherif Bassiouni considers that these broad and systematic terms have two clear intentions. First, to eliminate spontaneous or uncontrolled group conflicts from the scope of crimes against humanity, and secondly, to reflect the country's actions or policies committed by state actors and elements of the system for non-state actors. (Hasiholan Gultom, n.d.) Meanwhile, the International Criminal Tribunal for Rwanda (ICTR) interprets the systematic meaning as a thoroughly organized action. It follows an orderly pattern based on a standard policy that concerns or involves substantial public or private resources. In contrast, a crime is widespread or committed on a large scale with a cumulative effect on a series of inhuman actions or the singular effect of an act of extraordinary magnitude (Hasiholan Gultom, n.d.).

Thus, a crime against humanity or often referred to as a Gross Human Rights Violation if such action is part of the country's politics, which is carried out widely and systematically by the Government or facilitated by the Government.

In contrast to the grand humanitarian law, as mentioned above, humanitarian law protects individuals' interests as a result of armed strife. So here is also the State's obligation as parties in the armed conflict to protect individuals suffering from the armed conflict. Violation of humanitarian law is classified as a war crime. So when a country or individual involved in an international armed dispute violates the laws and customs of war, including violating the provisions in the 1949 Vienna Convention following Additional Protocol I 1977 then they can be said to have committed war crimes (Azzolini, 1997).. 
Al Qodar Purwo Sulistyo,

Levina Yustiningtyas

pp. $94-104$
E-ISSN : 2723-2476

Issn : 2723-1968

ACLJ, Vol. 1, Issue 2, 2020
Under the London Agreement of August 8 1945, it was agreed to be established by the Court of Justice in Nurenberg and the international military court for the Far East in Tokyo. In the agreement, it is asserted that the crimes that can be tried are war crimes, namely violations of the rule of law and war customs. In comparison, the other crimes on trial are crimes against peace and crimes against humanity.

War crimes themselves are formulated as unlawful crimes and war habits committed in wartime by both citizens of enemy states and foreigners who serve the enemy (Haryomataram, 2000). To describe war crimes, the Geneva Convention 1949 uses the term grave breaches, as stipulated in Article 50 of Convention I:

Grave breaches intended by the previous article are offenses that include the following acts if committed against persons or property protected by the convention; involuntary manslaughter, mistreatment or inhumane treatment, including biological experimentation, intentionally causing great suffering or severe injury to body or health; and widespread destruction and unlawful destruction of property that is not permitted by military interests and carried out unlawfully.

As it is known that the provisions contained in humanitarian law only provide a general framework for violations. Both the Geneva Conventions of 1949 and Protocol I of 1977 distinguish between gross violations and other acts contrary to humanitarian law provisions. In the Geneva Conventions and additional protocols governing actions that include as gross violations, whereas acts other than gross violations contrary to humanitarian law are not mentioned in the Geneva Conventions 1949 and Protocol I. However meaningless for an unlawful act and not included in the list of gross violations would constitute a minor violation, it is necessary to consider the provisions of the law in other Conventions as well as international customs law (Azzolini, 1997).

The types of actions that include War Crimes (gross violations) as stipulated in the 1949 Geneva Conventions are:

1. Intentional killing,

2. Torture or inhuman treatment, including biological experimentation,

3. Intentionally causing serious suffering or serious injury to the body or health,

4. Extensive destruction and takeover of property, which is not justified in terms of military interests and carried out deliberately and against the hokum,
5. Forcing a man of war or another protected person to serve in an enemy army ruler,

6. By deliberately waiving the right of a prisoner of war or another person to be protected for his right to an honest and orderly trial,

7. Unlawful deportation or unlawful removal,

8. A un martyred restraint.

9. Standoff.

While actions that include war crimes or gross violations of humanitarian law, contained in protocol 1 are:

1. Any act that could harm physical or mental health or integrity,

2. Intentionally perform acts that cause death or severe injury to body or health, such as:

a. attacks on civilians,

b. blind attacks that harm civilians or civilian objects,

c. attacks aimed at installations containing dangerous forces,

d. attacks on indefensible villages,

e. attacks on people who no longer participate in combat,

f. misuse of protective marks.

3. Intentionally perform the following actions:

a. deportation of some of the occupied civilian population,

b. delays in the handling of prisoners of war and civilians,

c. degrading acts of human dignity and discrimination,

d. attacks on historical objects, places of worship, cultural objects,

e. disrespect of persons protected by the Convention on Geneva.

3. Not performing any obligations as stipulated in the Geneva Conventions

While unserious violations include the actions of:

1. Any act that is not declared to be a gross violation but contrary to international humanitarian law established for global armed strife,

2. Any violation that is not declared as a gross violation but caused by not being fully obliged to act following international humanitarian law (Haryomataram, 2000).

Thus both in human rights law and in humanitarian law known as Gross Violations (Tani, 2019) In human rights law, serious violations occur when such violations involve or are facilitated by the 
Government, are carried out systematically and widespread, and are part of state policy. As for gross violations of humanitarian law, grave breaches occur because such actions include actions specified in the 1949 Vienna Convention or in Protocol I of the Geneva Conventions of 1949. There have been serious human rights violations and gross violations of humanitarian law when associated with disputes between Israel and Palestine, so Israel's actions have complied with the element of a gross violation of humanitarian law. Israel's actions have resulted in the killing of thousands of civilians and the destruction of civilian facilities and infrastructure, including worship.

\section{Individual Actions That May Give Rise to State Responsibility}

The State inaction is through an individual acting as a state organ, state representative, or state official, so is not responsible for the individual's actions unless the individual acts on behalf of the State. actions of individuals acting on behalf of that country may result in state responsibility, if:

1. such actions are a violation of international law;

2. according to international law, such violations may be bestowed upon the State.

According to Cassese (Cassese, 2005), there are several categories where individual activities can be considered attributable to other countries, namely:

1. act on the instructions of the State;

2. act under state control;

3. in fact, act as a state official.

From the above description, it can be known that individuals' actions that can be bestowed upon the State to date there is no definitive arrangement. But in Article 4 of the International Law Commission (ILC) Draft Articles Responsibility of State for Internationally Wrongful Acts 2001 mentioned concerning the actions of state organs that can give rise to state responsibilities, namely:

1. The conduct of any State organ should be considered an act of that State under international law, whether the organization of the State, and whatever its character as an organ of the central Government or of the tetitorial unit of the State.

2. An organ includes any person or entity which has that status in accordance with internal law of the State.
In addition to the actions of the state organs mentioned in Article 4 of the International Law Commission (ILC) Draft Articles Responsibility of State for Internationally Wrongful Acts 2001, it still mentions other measures that can be attributed to the State, namely:

1. The conduct of a person or entity which is not an organ of the State under Articles 4 but which is empowered by the law of that State to exercise elements of governmental authority should be considered an act of the State under international law, provided the person or entity is acting in that capacity in the particular instance (Article 5);

2. The conduct of an organ placed at the disposal of a State by another State shall be considered an act of the former State under international law if the organ is acting in the exercise of element of the governmental authority of the State at whose disposal it is placed (Article 6);

3. The conduct of an organ on a State or of a person or entity empowered to exercise elements of the governmental authority should be considered an act of the State under international law if the organ, person or entity acts in that capacity, even if it exceeds its authority or contravenes instructions (Article 7);

4. The conduct of a person or group of a person shall be considered an act of a State under international law if the person or group of person is in fact acting on the instruction of, or under the direction or control of, that State is carrying out the conduct (Article 8);

5. The conduct of a person or group or person should be considered an act of a State under international law if the person our group of persons is in fact exercising elements of the governmental authority in the absence or default of the official authorities and in the circumstances such as to call for the exercise of those elements of authority (Article 9);

6. Article 10 :

a. The conduct of an insurrectional movement that becomes the new Government of a State should be considered an act of that State under international law.

b. The conduct of movement, insurrectional or other, which succeeds in establishing a new State in part of the territory of a pre-existing State or in territory under its 
Al Qodar Purwo Sulistyo,

Levina Yustiningtyas

pp. $94-104$
E-ISSN : 2723-2476

Issn : 2723-1968

ACLJ, Vol. 1, Issue 2, 2020 administration, should be considered an act of the new State under international law.

c. The articles are without prejudice to the attribution to a State of any conduct, however, related to that of the movement concerned, which is to be considered an act of that State by virtue of articles 4 to 9 .

The actions of individuals acting on behalf of that country may be bestowed upon the country, which causes the State to be held accountable. Regarding the terms of the current forms of indemnity, there is no definitive arrangement. The ILC Draft Articles Responsibility of State for Internationally Wrongful Acts 2001 states that forms of damages incurred in the form of restitution, compensation, and satisfaction. As a form of accountability, the State must provide compensation to the aggrieved country, which can be:

1. Restitution

An act to restore the situation with everything possible, until the original State is achieved as if nothing had happened.

2. Compensation

In the form of payment of a certain amount of money compared to the losses suffered. Compensation must include all losses incurred.

3. Pemuasan

Efforts to repaid losses that cannot be paid for with money such as honors or state prestice. The reening can be done with a formal apology, a formal admission of guilt, a promise not to re-convict, and punish the infringing state official.

Enforcement in the Application of Distinction Principle as a consequence of Israeli aggression into Palestine

The conflict between Israel and Palestine is actually a conflict that occurs between Israel as a State and the armed groups (military wing) of Hamas. This type of armed conflict can be categorized as armed conflict stipulated in Additional Protocol II 1977, which is about non-international armed conflict as outlined in his book Alina Permanasasri on types of armed conflict (Cassese, 2005).

The armed conflict that occurred between Israel and Hamas that occurred in the Palestinian territories in July 2014 can be categorized as an armed conflict in the category of non-international armed conflict if viewed from the point of view of the status of the parties directly involved in the conflict, namely Israel as a State while Hamas is a political party in Palestine that is a non-state actor (non-state actor)that characterizes as an organized armed group.

But on the one hand, the armed conflict between Israel and the Palestinians can also be referred to as an international conflict because of the widespread and devastating impact on the Palestinian population and the aftermath of these Israeli attacks has succeeded in destroying the government and infrastructure facilities that exist in Palestine, so Lebanon suffers great losses as a result of the war inflicted, and Israel is considered still to be able to take responsibility for the misery that occurs in Palestine.

The Geneva Iv Convention of 1949 governs noninternational armed conflict stipulated in Article 3 of the common articles) (Permanasari, 1999). The provision only guarantees the protection of residents in armed conflicts who are not classified in international armed conflicts but does not provide a clear understanding of the practice. Article 3 of the Geneva Convention IV of 1949 have not formulated a situation or situation effective, nor has it provided objective criteria to be applied. According to Arlina Permanasari this is both a weakness and an advantage because Article 3 of the Geneva Convention IV of 1949, it does not reject any broad interpretation (Permanasari, 1999).

According to Arlina Permanasari method to know about this can be searched through the search for comments or a summary of the results that occurred at the time of the establishment of the convention (commentary), and the opinions of experts (Jauhari Ginting \& Indah Kurnia Ningsih, 2019). Commentary of the Convention formulates the terms to determine the case of an armed conflict. Such terms, among others, contain stipulated that an armed movement that is a party to an armed conflict has an organization that has the same nature as the State. There is a civil authority exercising its control over people in a particular territory, and that the armed forces act under the control of an organized civilian ruler (Permanasari, 1999). Hamas is a political organization that has considerable influence in the State of Palestine.

The armed conflict between Israel and the Palestinians has also been included in the U.N. agenda, which led to a new resolution on armed violence between the warring parties. This is also one of the conditions contained in the Commentary of the Geneva Conventions of 1949 (Permanasari, 1999).

Determination of the type of armed conflict that occurs can also be formulated by classifying the concept of armed conflict itself (Permanasari, 1999). In fact, there are several types of non-international armed 
conflicts, but the Geneva Convention of 1949 itself does not provide a clear definition of this type of conflict. In Geneva Convention 1949, it only gives the understanding that this type of conflict is the type of armed conflict that is not an international armed conflict it is contained in Article 3 of the 1949 General Convention (Permanasari, 1999).

Convergent participants finally determined that special attention was needed on how to determine whether or not a non-international armed conflict had occurred, namely (Permanasari, 1999) :

1. determine the highest and highest threshold of non-international armed conflict;

2. determine what elements of the definition of non-international armed conflict;

3. ensure that the implementation of Article 3 of the Geneva Conventions of 1949 remains in effect.

The armed conflict between Israel and Hamas has met the first and second criteria of the above requirements. The deployment of the armed forces on a large scale through an official military operation carried out by the Israeli military forces and the fall of many casualties both among civilians and casualties stemming from combatants if it can be used as a benchmark to determine the ongoing non-international armed dispute between Israel and Hamas. Israel stresses that the policy of arms lifting in Palestine is nothing more than an attempt to defend itself in retaliation for attacks carried out by Hamas.

The Palestinian conflict between Israel and Hamas is politically motivated, heavily influenced by other forces outside the conflict. Every time Israel launches an attack on Hamas, it will receive protection from the United States (U.S.). An example is when Israel launched major attacks on Lebanon in 1978, 1982, 1993, and 1996. For instance, U.S. Secretary of State Warren Christopher threw responsibility to Hezbollah for the outbreak of war in Lebanon in 1996. The United States threatened to use a veto if the U.N. Security Council tried to issue a resolution on Israel's in an attack on Lebanon. On the contrary, Hezbollah has always begun to take the initiative to launch military attacks on defense zones in Israel-occupied South Lebanon whenever Syria or Iran experience political difficulties in regional and international areas (DetikNews, 2014).

The interests of the United States and Israel are to meet in Israel's attack mission with the Palestinians. Israel is interested in paralyzing Hamas bases across
Palestine to secure Northern Israeli territory in order to secure the radical Lebanese faction. Meanwhile, the United States and Israel are also aiming for revenge against Hamas' promoter, Jihad Islamiah. Both are thought to be behind the violence committed by other Middle Eastern radical factions such as Hezbollah promoted by Syria and Iran (DetikNews, 2014).

The United Nations, as the world's largest and most influential international organization, has the responsibility for maintaining world peace, cannot expressly impose sanctions on Israel. Israel is under the United States' protection and the other factor that causes the United Nations to impose sanctions on Israel unequivocally. After all, America is the largest funder in the United Nations. With America's absence as the largest funder factor until now, the crisis in the Middle East due to Israel's actions has not been completed. The perpetrators of these violations have not been able to be dragged before the International Criminal Court. However, it is clear that Israel's offensive actions are categorized as gross violations of international humanitarian law provisions.

\section{CONCLUSION}

Based on the description of the discussion of the above issues, it can be concluded that in the enforcement of international humanitarian law, several weaknesses do not run the maximum, namely the weak provisions on international procedures that apply the effectiveness of international law can be enforced if it has been implemented in the national law of each country, weak awareness of each country to implement the rules of international humanitarian law in the national law of each country and weak sanctions from international organizations for violations of international humanitarian law so as to cause the perpetrators to expand the attacks freely.

\section{References}

Arianta, K., Gede, D., Mangku, S., Putu, N., Yuliartini, R., Hukum, J. I., \& Ganesha, U. P. (2020). PERLINDUNGAN HUKUM BAGI KAUM ETNIS ROHINGYA DALAM PERSPEKTIF HAK ASASI MANUSIA INTERNASIONAL. Journal Komunitas Yustitia, 3(2), 166-176. Retrieved from https://ejournal.undiksha.ac.id/index.php/jatayu/ article/view/28849/16358 
Al Qodar Purwo Sulistyo,

Levina Yustiningtyas

pp. $94-104$
E-ISSN: 2723-2476

Issn : 2723-1968

ACLJ, Vol. 1, Issue 2, 2020
Azzolini, C. (1997). Hukum Humaniter suatu Prespektif. Jakarta.

Cassese, A. (2005). International Law. New York: Oxford University Press Inc.

DetikNews. (2014). Politik AS, dibalik serangan Israel dalam konflik Timur Tengah,. Retrieved March 20, 2015, from www.detik.com

Fadila, Y. (2014). 10 Hal Yang harus Kamu Tahu Soal Gaza Sebelum Ikut-Ikutan Komentar. Retrieved from hipwee website: https://www.hipwee.com/feature/10-hal-yangharus-kamu-tahu-soal-gaza-sebelum-ikut-ikutankomentar/

Hans-Peter, G. (n.d.). International Humaniter Law an Introduction,. Hendri Dunant Institute, Haupt.

Haryomataram. (2000). Hukum Humaniter. Jakarta: Rajawali Press.

Hasiholan Gultom, E. (n.d.). Kompetensi Mahkamah Pidana Internasional dalam Peradilan Kejahatan Terhadap Kemanusiaan di Timor Timur. Jakarta: Tatanusa,.

Jauhari Ginting, \& Indah Kurnia Ningsih. (2019). Perlindungan hukum terhadap pekerja pt. mara jaya dalam hal kebebasan berserikat menurut Undang-undang RI nomor 21 tahun 2000 tentang serikat pekerja. Jurnal Hukum Kaidah: Media Komunikasi Dan Informasi Hukum Dan Masyarakat, 19(1), 69. Retrieved from https://jurnal.uisu.ac.id/index.php/jhk/article/vie w/1907

Muladi. (1998). Prinsip-Prinsip pembentukan Pengadilan HAM di Indonesia dan Pengadilan Pidana Internasional. 11. Jakarta.

Muladi. (2000). Pengadilan Pidana bagi Pelanggar HAM Berat di Era Demokrasi. Jurnal Demokrasi Dan HAM, 1(1), 43-44.

Permanasari, A. (1999). Pengantar Hukum Humaniter. Jakarta: International commite of the red cross.

Rizal, M. (2016). EKSISTENSI PRINSIP-PRINSIP

HUKUM ISLAM TERHADAP

PENGATURAN PERANG DALAM HUKUM

HUMANITER INTERNASIONAL. Jurnal Ilmu
Hukum Legal Opinion, 4(2), 1-13. Retrieved from https://www.neliti.com/publications/151002/eksi stensi-prinsip-prinsip-hukum-islam-terhadappengaturan-perang-dalam-hukum-hu

Sassoli, Marco, et. a. (1999). How Does Law Protect in War?, Prosecutor v. Tadic, Case, No. IT-94I-AR 72. Geneva.

Tani, Q. C. F. (2019). KAJIAN HUKUM HUMANITER DAN HAM MENGENAI PELANGGARAN TERHADAP PRINSIPPRINSIP KEMANUSIAAN TAWANAN PERANG. Lex Et Sociatis, 7(3). Retrieved from https://ejournal.unsrat.ac.id/index.php/lexetsociet atis/article/view/24673/24384

US. (n.d.). Intruksi Lieber.

Wahyu, P. (2018). PENERAPAN PRINSIP PEMBEDAAN (DISTINCTION PRINCIPLE) DALAM PERLINDUNGAN PENDUDUK SIPIL (CIVILIANS) DALAM KONFLIK BERSENJATA DI SURIAH. Universitas Andalas.

Wikipedia. (2014). Konflik Israel-Gaza 2014.

Yustitianingtyas, L. (2007). Peran Dewan Keamanan PBB dalam Konflik Bersenjata Internasional (studi kasus; Agresi Israel ke Lebananon Tahun 2006. Universitas Gadjah Mada.

Zouhair Al Hassani. (2008). International Humanitarian Law and its Implementation in Iraq. International Review of the Red Cross, 90(86), 65-67. 